Vol. 7, No. 1, 2020

https://doi.org/10.23939/eem2020.01.001

UDC 336.225

JEL Clasification Code: F23, G32

\author{
I. Alieksieiev \\ Lviv Polytechnic National University, Ukraine, Doctor of Economics, Professor \\ e-mail: ihor.v.alieksieiev@1pnu.ua \\ ORCID: 0000-0001-6618-3100
}

S. Paranchuk

Lviv Polytechnic National University, Ukraine, Ph. D, Professor

e-mail: stepan.v.paranchuk@lpnu.ua

ORCID: 0000-0002-2255-4720

\author{
O. Chervinska \\ Lviv Polytechnic National University, Ukraine, Ph. D, Associate professor \\ e-mail: oksana.s.chervinska@lpnu.ua \\ ORCID: orcid.org/0000-0002-6048-7936
}

\title{
MONITORING OF TAX AND NON-TAX FLOWS
}

\begin{abstract}
The filling of budgets at all levels is crucial for the implementation of national and regional programs of socio-economic development. Tax and nontax revenues are exactly the fillers. A key source of revenue for the budget system was and remains tax revenue. However, the worldwide taxation practice shows that budgetary entities are primarily failing to fulfill their obligations. The fraud of taxpayers makes it necessary to retain special fiscal bodies, which are responsible for controlling the amount and timeliness of taxes, both legal and private persons. The problem of tax revenue is a problem in all countries, but it is very acute in Ukraine. An important component of the problem is identifying tax arrears and ensuring that debtors make payments to the budget system. The solution to this problem should be based on the domestic tax policy and the methods set out therein to ensure tax revenues to the budget system. It is generally accepted that tax compliance requires external control and audit of taxpayers. Control is a necessary tool not only to determine the correctness of tax charges, but also to stimulate their timely implementation. Monitoring has been and remains an important aspect of tax policy implementation, ant it is quite voluminous by its functions. It is stated that in addition to keeping track of planned figures for tax and non-tax payments to budgets,
\end{abstract}

monitoring should also address the effectiveness of taxation methods used. Monitoring will only be effective if researchers and practitioners of the State Fiscal Service (SFS) receive answers to key questions of taxation and budgeting at all levels. Purpose of the work is to study the dynamics of payment of taxes, levies, payments, which is an important result of all tax activities, including the SFS measures to monitor the status of tax and non-tax (financial) flows, first and foremost, the tax additional charges. An analysis of the publications of the results of the research showed that the problem of tax charges is not given enough attention. It is obvious that the flow of additional tax charges, which is not actually too large today, is not so interesting to researchers and, as evidenced by tax practice, also to fiscal practitioners. Instead, given the large size of the shadow economy, tax evasion through optimization schemes, due to the occurrence of tax arrears due to the improper performance of contractual obligations, should be considered as a potentially significant flow of additional tax charges. The above identified the hypothesis of the study of the problem and its solution in the process of monitoring tax and non-tax flows. The research methodology for this hypothesis is to find the reasons that lead to the need to calculate the amount and payment of tax charges by the entity, as well 


\section{Alieksieiev, S. Paranchuk, O. Chervinska}

as to determine the stages of monitoring. The study of the first of the stages of monitoring tax and non-tax flows, including the flow of tax charges, is the content of this publication. The statistical method, as well as the methods of analysis, synthesis and generalization, were used for this purpose. Analysis of tax and non-tax revenues (payments) to ensure the formation of state and local budgets is made. Structure of actual revenues and expenditures of general and special funds of the state budget of Ukraine is calculated and analyzed. An undulating nature of shares of tax flows in the total amount of consolidated budget revenues is noted. Weights of tax and non-tax flows in the consolidated budget of Ukraine for the studied period 2014-2018 are compared. It is recorded that the taxation system in Ukraine is constantly influenced by reform initiatives. Changes in the composition of governments lead to transformations of the taxation system. Tax rates are changed most often and it reflects the interests of those financial and industrial groups that control the government. In addition, from time to time there are requests from the public for introduction or cancellation of certain taxes, changes in preferential taxation regimes, control of accrual correctness, completeness and timeliness of payment by taxes, levies or payments.

Key words: monitoring of tax and non-tax (financial) flows, tax and non-tax (financial) flows, tax deduction stream, timing of inspections, optimization of work of the state fiscal service.

\section{Introduction}

The reforms that have been implemented in Ukraine for several decades require considerable financial resources. Since the reforms are initiated and implemented by the government, it is generally recognized that the main financial source is the state budget. Mobilization of funds to the state budget is carried out through tax and non-tax revenues. Pursuant to the current legislation $[1 ; 2$; $3 ; 4 ; 5 ; 6]$, a key aspect of attracting the funds to the state budget is administration of taxes. It is the successful administration of taxes by the bodies of the State Fiscal Service of Ukraine as well as the Customs Service of Ukraine, that allows formation of the necessary revenue of state and local budgets, which is a prerequisite for ensuring the expenditures of budgets of all levels.

However, it is common knowledge that the budget systematically underreports significant tax revenue for a variety of reasons. On the one hand, there is a large part of the shadow economy, the size of which differs from different researchers, but according to Ukrinform, in 2017 it was $46.8 \%$ and grew in 2018 to $47.2 \%$ of GDP [7]. The Kiev International Institute of Sociology (KIIS) conducted research on the shadow economy in 2017 and 2018 and identified certain components of the shadow economy: salary in envelopes $18.3 \%$ (2017) and $21.4 \%$ (2018), unregistered employees - $21.4 \%$ (2017) and $21.9 \%$ (2018), undeclared business income $-60.2 \%$ (2017) and $56.7 \%$ (2018) [8].

On the other hand, as it is a worldwide practice, businesses seek to pay a minimum of taxes using so-called tax optimization methods [9]. There are consulting companies that provide tax optimization services [10; 11].

Another reason for not receiving tax payments is the temporary inability of businesses to pay their taxes due to financial difficulties. Some companies have already been declared bankrupt, others are in the process of recognizing such status, they are actively functioning, but they have arrears both in payment of wages and in payment of taxes, as evidenced by official data $[12,13]$. Also, these aspects of the problem of financial and economic insolvency of enterprises are investigated by scientists, in particular [14].

The monitoring of tax payments aims to identify those businesses that have problems with paying taxes, to identify the causes of these problems, including the exposing of entrepreneurs' intentions to avoid tax. Such monitoring should result in the payment of tax arrears. In doing so, taxpayers should determine the amount of the deduction, given the circumstances of the delay in tax compliance of enterprises. The problem of additional tax charges should be seen as a complex one, part of which is to monitor and the other to determine the amount of additional tax collection as debt or intentionally unpaid tax. The problem with our study is the monitoring of additional tax charges.

\section{Literature review}

Execution of tasks of socio-economic development of state in the tax area begins with formation of tax policy, which is emphasized by T. I. Yefymenko, O. T. Zamaslo, Y. B. Ivanov, A. I. Krysovatyi, M. I. Krupka and A. M. Sokolovska 


\section{Monitoring of tax and non-tax flows}

$[7 ; 8 ; 9 ; 10 ; 11 ; 12 ; 13 ; 14]$. At this, we should note that many negative aspects have not been overcome yet, and this have been noted for a long time. Thus, in 2007, T. I. Yefimenko wrote about multiple taxation [15]. V. M. Melnyk and T. V. Koshchuk wrote about the need for correction of the tax policy of Ukraine [16]. We have noted in previous publications that However, taxation system has not yet been simplified, which is needed to facilitate business operations [17]. It is the work by O. T. Zamaslo, which is dedicated to further development of the taxation system with respects to European integration requirements and peculiarities of economic development in the second decade of the 21st century [9].

Monitoring has been and remains an important aspect of tax policy implementation. Monitoring of tax activity is quite voluminous by its functions. After all, addition to keeping track of planned figures for tax and non-tax payments to budgets, monitoring should also address the effectiveness of taxation methods used. Monitoring will only be effective if researchers and practitioners of the State Fiscal Service (SFS) receive answers to key questions of taxation and budgeting at all levels. Undoubtedly, the main result of the SFS activity is the increase of tax flows, increase of budgetary revenues.

Many studies have been devoted to monitoring problems in the tax field, on the basis of which a number of recommendations have been proposed to improve the filling of budgets at all levels through tax revenues. Article V. Khomutenko and I. Lutsenko are devoted to the research of monitoring of tax revenues to the consolidated budget of Ukraine [26, p. 292-302]. I. Lutsenko's publication is devoted to a separate aspect monitoring of tax revenues to the state budget of Ukraine from foreign trade activity [27, p. 62-66]. The results of estimating budget risks in forming the state budget revenue base are outlined in the work of V. Babichenko, V. Glukhova, and Y. Kolotiy [28, c. 19-25]. L. Zakharkina built her study of tax revenues to the consolidated budget of Ukraine on determining the indicator of 'elasticity of the budget revenue system' [29, p. 125], which allowed us to show the high level of the "shadow" economy in Ukraine. In particular, it defines periods of significant tax evasion by type of tax:
VAT, excise duty, corporate income tax [29, p. 128]. Based on the objectives of our study, we can state that there is a significant field of activity for the accrual of unpaid taxes.

Special attention should be paid to the works of Ukrainian scientists, which deal with the problems of tax administration and tax regulation along with the problems of monitoring tax revenues. O. Zolotareva and I. Kostenko devoted their research to the study of the optimality of the structure of revenues to the state budget. In particular, the indicator of the development of the income system, the authors chose the relationship between tax and non-tax revenues [30, p. 534]. Based on the results of the calculations, they concluded that "the critically poor accuracy of these tax returns" [30, p. 541]. It also confirms that there are good reasons for additional checks and tax payments. Although the authors do not emphasize such a possible conclusion from the results of their research. Instead, the authors provide information on TADAT's International Tax Administration Assessment Diagnostic Tool (citing [31]), which encompasses nine key performance areas (QFs). One of these areas, namely "COR 5: Timely Payment of Tax Liabilities," contains "P5-15. The volume and dynamics of tax debt". That is, we can conclude that international practice involves the impossibility of both inaccuracy in tax information and the need to collect debt.

The problems of tax regulation are devoted to the publications of A. Nikitishina. At work [32, p. 300-307] the author presents the results of the study of adaptive and coherent institutional architecture of tax regulation. Interesting from the point of view of tax debt is the author's conclusion about its impact on the "launch of a negative chain reaction across the institutional architecture of the country, even beyond its borders [32, p. 303]. In another article [33], A. Nikitishin, in studying the directions of improving the mechanism of tax regulation, draws attention to the reforms of international tax systems, which envisaged "counteracting the erosion of the tax base and the removal of profits from taxation". The statistics on the amounts of taxes received are \$ 100-240 billion. USA. Among the measures taken by the governments of foreign countries are named, in particular, "combating fraud and tax evasion" [33]. 


\section{Alieksieiev, S. Paranchuk, O. Chervinska}

A. Mykolayets devoted his research to the problems of tax control. In particular, the author points out the "additional charges for various payments" in connection with the implementation of tax control functions and the classification of this issue as one of the types of tax control. He writes: "Based on the main function of tax control, the purpose of which is to maximize the amount of extra charges to the budgets of all levels, that is, the fiscal function, until recently, the main type of tax control has been consistent".

Regarding local budgets, we should mention the publications of A. Nikitishin and Y. Sayenko on the formation of local budgets on the example of Vinnytsia region [35]; V. Glukhova and L. Skrypnyk on financial support for health care at the level of local budgets [36]. From the positions of the largest taxpayers on the sectoral and regional characteristics investigated tax revenues T. Goloborodko and S. Shmagaylo [37].

Combating tax evasion and tax arrears to replenish state and local budgets is an important aspect of the activities of the State Fiscal Service of Ukraine, the new State Tax Service. Head of the State Tax Service S. Verlanov, speaking about the prospects of implementation of the plan of tax revenues to the budget in the first quarter of 2020, noted that reducing the budget losses due to effective fight against tax fraud and increase tax revenues should lead to a decrease in additional charges revenues of tax revenues, and volumes of tax administration work (FINBALANCE, Finance and Economy, 02/21/2020, 5:00 pm).

Summarizing the scientific literature review of publications on monitoring budget revenues, we present the Table 1.

\section{Typologization of scientific researches of Ukrainian scientists in the field of monitoring of budget revenues}

\begin{tabular}{|c|c|c|}
\hline $\begin{array}{l}\text { An area where budget revenue } \\
\text { monitoring issues were investigated }\end{array}$ & $\begin{array}{l}\text { Issues related to the monitoring of budget } \\
\text { arrears and charges are investigated }\end{array}$ & $\begin{array}{c}\text { Researchers in the specified area } \\
\text { of monitoring }\end{array}$ \\
\hline \multicolumn{3}{|c|}{ Consolidated Budget of Ukraine } \\
\hline Monitoring of tax revenues & & Khomutenko V. and Lutsenko I. \\
\hline $\begin{array}{l}\text { Tax revenues from foreign } \\
\text { economic activity }\end{array}$ & & Lutsenko I. \\
\hline $\begin{array}{l}\text { Budget risks in forming the state } \\
\text { budget revenue base }\end{array}$ & & $\begin{array}{l}\text { Babichenko V., Glukhova V. } \\
\text { and Kolotiy Y. }\end{array}$ \\
\hline $\begin{array}{l}\text { The indicator of "elasticity of the } \\
\text { budget revenue system" }\end{array}$ & $\begin{array}{l}\text { The periods of significant tax evasion by } \\
\text { individual types of taxes have been } \\
\text { determined }\end{array}$ & Zakharkina L. \\
\hline $\begin{array}{l}\text { Implementation of the fiscal revenue } \\
\text { plan for the first quarter of } 2020\end{array}$ & $\begin{array}{l}\text { Reducing budget losses and reducing tax } \\
\text { payments }\end{array}$ & Verlanov S. \\
\hline \multicolumn{3}{|c|}{ Tax administration and tax regulation } \\
\hline $\begin{array}{l}\text { Optimality of the structure of } \\
\text { revenues to the state budget. An } \\
\text { indicator of the development of } \\
\text { the income system is the ratio } \\
\text { between tax and non-tax revenues. }\end{array}$ & $\begin{array}{l}\text { TADAT's International Diagnostic } \\
\text { Assessment Tool, including "the FRA 5: } \\
\text { Timely Payment of Tax Liabilities" and } \\
\text { "the P5-15 Indicator. Volume and } \\
\text { dynamics of tax debt". }\end{array}$ & $\begin{array}{l}\text { Zolotareva O. and } \\
\text { Kostenko I. }\end{array}$ \\
\hline $\begin{array}{l}\text { Research on adaptive and coherent } \\
\text { institutional architecture of tax } \\
\text { regulation. }\end{array}$ & & Nikitishin A. \\
\hline & Budgeting at all levels is a fiscal function & Mikolayets A. \\
\hline \multicolumn{3}{|c|}{ Problems with local budget revenues } \\
\hline On the example of Vinnytsia region & & Nikitishin A. and Sayenko Y. \\
\hline Health care budgeting & & Glukhova V. and Skripnik L. \\
\hline $\begin{array}{l}\text { Tax revenues from the largest } \\
\text { taxpayers by sectoral and regional } \\
\text { basis }\end{array}$ & & $\begin{array}{l}\text { Goloborodko T. and } \\
\text { Shmagaylo S. }\end{array}$ \\
\hline
\end{tabular}




\section{Monitoring of tax and non-tax flows}

Typologization, grouping of the studied problems of monitoring tax revenues allows to conclude that monitoring in the field of taxation is carried out for all levels of the budget system. Scientists and practitioners identify the most significant problems, develop tools to overcome identified weaknesses. Although the problems of debt are reflected in these studies, the focus is instead on monitoring the additional charges of tax revenues.

Purpose of the work is to study the dynamics of payment of taxes, levies, payments, which is an important result of all tax activities, including the SFS measures to monitor the status of tax and non-tax (financial) flows as a prerequisite for monitoring the additional charges of tax revenues.

\section{Methodological approach}

Tax and non-tax flows, as evidenced by research publications in this field, are incomplete due to tax evasion, tax optimization and so on. For this reason, monitoring of tax and non-tax payments is an important aspect for the full implementation of the budget revenue plan. This is the first - the statistical stage of monitoring the additional charges of tax revenues. The second step is to determine the amount of additional charges of taxes for a particular enterprise. Research methods should be: statistical, analysis and synthesis, generalization.

\section{The main materials}

Presented data (Table 2) shows that in the structure of tax revenues of the consolidated budget of Ukraine during 2014-2018 the largest shares had the following taxes: value added (VAT), which increased from $37.8 \%$ in 2014 to $37.9 \%$ in 2018 ; personal income tax (PIT), which also increased from $20.5 \%$ in 2014 to $23.3 \%$ in 2018; excise tax (ET) increased from $12.3 \%$ in 2014 to $13.4 \%$ in 2018; corporate income tax (CIT) was $10.9 \%$ in 2014 and decreased by $0.1 \%$ to $10.8 \%$ in 2018 . Thus, these four types of tax payments account for $81.5 \%$ $(37.8 \%+20.5 \%+12.3 \%+10.9 \%)$ in 2014 and $85.4 \%(37.9 \%+23.3 \%+5.1 \%+10.8 \%)$ in 2018 . During the four years, share of these taxes increased by $3.9 \%$. Instead, share of the rent in the consolidated budget of Ukraine has decreased from $10.8 \%$ in 2014 to $5.1 \%$ in 2018 . Weight of customs duties also significantly reduced: it amounted to $3.4 \%$ in 2014 , increased to $7.9 \%$ in 2015 , and then decreased to $2.7 \%$ in 2018. The same trend for decrease of the weight was observed for other taxes and levies, which in 2014 amounted to $2.1 \%$, and during 2015-2018 was gradually decreasing and reached the minimum value of $0.5 \%$.

Structure of tax revenues of the Consolidated Budget of Ukraine for 2014-2018*

\begin{tabular}{|c|c|c|c|c|c|c|c|c|c|c|c|}
\hline \multirow{3}{*}{ No. } & \multirow{3}{*}{ Indicators } & \multicolumn{10}{|c|}{ Years } \\
\hline & & \multicolumn{2}{|l|}{2014} & \multicolumn{2}{|l|}{2015} & \multicolumn{2}{|c|}{2016} & \multicolumn{2}{|l|}{2017} & \multicolumn{2}{|l|}{2018} \\
\hline & & thous. UAH & $\%$ & thous. UAH & $\%$ & thous. UAH & $\%$ & thous. UAH & $\%$ & thous. UAH & $\%$ \\
\hline 1 & PIT & 75202945.3 & 20.5 & 99983173.9 & 19.7 & 138781786.5 & 21.3 & 185686131.6 & 22.4 & 229900604.4 & 23.3 \\
\hline 2 & CIT & 40201485.7 & 10.9 & 39053168.6 & 7.7 & 60223231.5 & 9.2 & 73396802.8 & 8.9 & 106182347.5 & 10.8 \\
\hline 3 & Rent payment, RP & 39584203.6 & 10.8 & 49203618.8 & 9.7 & 46608398.3 & 7.2 & 51132329.1 & 6.2 & 50086888.8 & 5.1 \\
\hline 4 & Excise tax, ET & 45099574.7 & 12.3 & 64795226.3 & 12.8 & 101750661.7 & 15.6 & 121449435.6 & 14.7 & 132649809.5 & 13.4 \\
\hline 5 & VAT & 139024258.8 & 37.8 & 178452385.2 & 35.2 & 235506029.9 & 36.2 & 313980594.4 & 37.9 & 374508186.5 & 37.9 \\
\hline 6 & Customs duties & 12608696.0 & 3.4 & 40300805.6 & 7.9 & 20370979.9 & 3.2 & 24541812.4 & 2.9 & 27076620.9 & 2.7 \\
\hline 7 & Local taxes & 8055639.5 & 2.2 & 27041345.0 & 5.3 & 42261496.7 & 6.5 & 53270112.5 & 6.4 & 61019496.7 & 6.3 \\
\hline 8 & $\begin{array}{c}\text { Other taxes and } \\
\text { levies }\end{array}$ & 7735127.2 & 2.1 & 8806176.3 & 1.7 & 5279094.1 & 0.8 & 4701595.5 & 0.6 & 4924569.2 & 0.5 \\
\hline 9 & Tax revenues & 367511931.1 & 100 & 507635899.7 & 100 & 650781678.6 & 100 & 828158813.9 & 100 & 986348523.5 & 100 \\
\hline 10 & Non-tax revenues & 80612762.6 & - & 140154438.7 & - & 125502878.2 & - & 154552067.1 & - & 192716615.4 & - \\
\hline 11 & Other revenues & 7942629.7 & - & 4240655.9 & - & $6,574928.2$ & - & 34258627.2 & - & 5225626.0 & - \\
\hline 12 & $\begin{array}{l}\text { Total revenues } \\
\text { (excluding } \\
\text { intergovernmental } \\
\text { transfers) }\end{array}$ & 456067323.5 & - & 652030994.4 & - & 782859484.9 & - & 1016969508.1 & - & 1184290765.3 & - \\
\hline
\end{tabular}

Source: compiled by authors using the data of the Ministry of Revenues of Ukraine: [web-site]. - Available at: http://www.minfin.gov.ua/control/uk/publish/archive/main?cat_id=77440 


\section{Weights of different taxes in tax revenues of the Consolidated Budget} of Ukraine for the period of 2014-2018*

\begin{tabular}{|c|c|c|c|c|c|c|c|c|c|c|c|}
\hline \multirow{3}{*}{ No. } & \multirow{3}{*}{ Indicators } & \multicolumn{10}{|c|}{ Years } \\
\hline & & \multicolumn{2}{|l|}{2014} & \multicolumn{2}{|l|}{2015} & \multicolumn{2}{|l|}{2016} & \multicolumn{2}{|l|}{2017} & \multicolumn{2}{|l|}{2018} \\
\hline & & thous. UAH & $\%$ & thous. UAH & $\%$ & thous. UAH & $\%$ & thous. UAH & $\%$ & thous. UAH & $\%$ \\
\hline 1 & Tax revenues & 367511931.1 & 80.6 & 507635899.7 & 77.8 & 650781678.6 & 83.1 & \begin{tabular}{|l|l|}
828158813.9 \\
\end{tabular} & 81.4 & 986348523.5 & 83.3 \\
\hline 2 & Non-tax revenues & 80612762.6 & 17.7 & 140154438.7 & 21.5 & 125502878.2 & 16.1 & 154552067.1 & 15.2 & 192716615.4 & 16.3 \\
\hline 3 & Other revenues & 7942629.7 & 1.7 & 4240655.9 & 0.7 & $\begin{array}{l}6,574928.2 \\
\end{array}$ & 0.8 & 34258627.2 & 3.4 & 5225626.0 & 0.4 \\
\hline 4 & $\begin{array}{c}\text { Total revenues (excluding } \\
\text { intergovernmental transfers) }\end{array}$ & 456067323.5 & 100 & 652030994.4 & 100 & $782859484.9 \mid$ & 100 & 1016969508.1 & 100 & 1184290765.3 & 100 \\
\hline
\end{tabular}

Source: compiled by authors

Table 4

Share of additional accruals in the value of tax revenues of the Consolidated Budget of Ukraine for the period of 2014-2018

\begin{tabular}{|c|c|c|c|c|c|c|}
\hline \multirow{2}{*}{ No. } & Indicators & \multicolumn{5}{|c|}{ Years } \\
\cline { 3 - 7 } & & 2014 & 2015 & 2016 & 2017 & 2018 \\
\hline 1 & Tax revenues, thous. UAH & 367511931.1 & 507635899.7 & 650781678.6 & 828158813.9 & 986348523.5 \\
\hline 2 & $\begin{array}{c}\text { Additional accrual of monetary } \\
\text { liabilities, thous. UAH }\end{array}$ & 7963822.0 & 4611007.0 & 6103433.0 & 16300557.0 & 13232296.0 \\
\hline 3 & Share of additional accruals, \% & 2.17 & 0.91 & 0.94 & 1.97 & 1.34 \\
\hline
\end{tabular}

Source: compiled by authors from the information presented on the web site of the SFS of Ukraine

An undulating nature of shares of tax flows in the total amount of consolidated budget revenues should also be noted. If absolute values of VAT, personal income tax, excise tax, local taxes were constantly increasing, their specific weights fluctuated. Corporate income tax (CIP) in absolute terms decreased in 2015 compared to the previous year, and during 2015-2018 we have a significant increase in tax revenues amounting to $271.9 \%$ $(106,182,347.5$ thousand UAH/ 39,053,168.6 thousand UAH). It should also be noted, that its weight in the total amount of tax revenues during 2015-2017 decreased, and in 2018 it almost reached the level of 2014.

To compare the importance of tax and nontax flows in the consolidated budget of Ukraine for the studies period, we should consider the data given in Table 3. The figures show that tax and non-tax revenues make up the bulk of the consolidated budget's revenue. The highest tax and non-tax revenues were received in 2017-2018, which is respectively $96.6 \%(81.4 \%+15.2 \%)$ and $99.6 \%(83.3 \%+16.3 \%)$ in the total the volume of revenues of the consolidated budget of Ukraine, i.e. the share of revenues (excluding intergovernmental transfers) increased by $3 \%$ (99.6-96.6\%) [18, p. 5-10].

At the same time, the share of tax revenues increased from $77.8 \%$ in 2015 to $83.3 \%$ in 2018 , while the non-tax revenues decreased from $21.5 \%$ in 2015 to $16.3 \%$ in 2018.

Direction of improvement of the state budget policy in 2014-2018 was the introduction of innovations for the main types of taxes, which make up the major part of revenues of the Consolidated Budget of Ukraine revenues. For example, reforming of the tax system of Ukraine, namely, value added tax, personal income tax, corporate income tax, excise tax, which are the main budgetforming taxes of the Consolidated Budget of Ukraine, resulted in increase of the total share thereof to $82.3 \%$ in $2016,83.4 \%$ in 2017 and $85.4 \%$ in 2018 . This is due to the improvement of the taxation system: reduction of tax rates, abolition of unreasonable tax benefits, introduction of financial result, improvement of depreciation of fixed production assets, tax exemption, introduction of zero tax rate, provision of tax benefits for the payers, control of correctness of calculations, completeness and timeliness of payment of taxes, duties, payments by taxpayers, etc. 


\section{Monitoring of tax and non-tax flows}

Receipt of additional charges received in connection with violation of tax legislation of Ukraine (underpayment of taxes, levies, payments, payment of penalties and fines) is also important to the Consolidated Budget of Ukraine. The largest revenues (monetary liabilities) from additional charges (Table 4) were received in 2017 in the amount of 16,300,557.0 thousand UAH, in 2018 in the amount of $13,232,296.0$ thousand UAH, in 2014 year in the amount of 7,963,822.0 thousand $\mathrm{UAH}$, and in 2016 in the amount of $6,103,433.0$ thousand UAH. The smallest amount of additional charges was received in 2015, in the amount of $4,611,007.0$ thousand $\mathrm{UAH}$, which is less than in 2017 by $11,689,550.0$ thousand UAH, or $71.7 \%$ $(11,689,550.0 / 16,300,557.0)$ less; respectively, less than in 2018 by $8,621,289.0$ thousand UAH, which is $65.1 \%(8,621,289.0 / 13,232,296.0)$. At this, the largest share of additional accruals of monetary liabilities in tax revenues of the Consolidated Budget of Ukraine is $2.17 \%$ in 2014, $1.97 \%$ in 2017 and $1.34 \%$ in 2018; the lowest is $0.94 \%$ in 2016 and $0.91 \%$ in 2015. The undulating nature of tax revenues to the consolidated budget of Ukraine is obvious.

Taxation system in Ukraine is constantly influenced by reform initiatives. Changes in the composition of governments lead to transformations of the taxation system. Tax rates are changed most often and it reflects the interests of those financial and industrial groups that control the government. In addition, from time to time there are requests from the public for introduction or cancellation of certain taxes, changes in preferential taxation regimes, control of accrual correctness, completeness and timeliness of payment by taxes, levies or payments [3; 19, pp. 133-137].

\section{The conclusions and recommendations for further research}

In Ukraine, it is urgent to reduce the tax pressure on businesses, especially small and medium ones; this will increase the number of business entities that will voluntarily pay taxes, and this, respectively, will reduce the forced collection due to minor violations of tax legislation. Therefore, supervisory authorities (SFS of Ukraine) should systematically improve the quality of control and inspection activities. For example, in 2014, the Government of Ukraine launched a real reform of the controlling authorities, the main tasks of which were the following: to reduce the number of controlling bodies due to their "liquidation" or "merger"; introduction of administrative responsibility for controlling bodies inspectors for violation of tax control procedures; good planning of audit work (priority should be given to addressed audits that will not affect a business with no objective risk factors); change of deadlines for administrative appeals against decisions made by the SFS bodies (from 10 calendar days - up to 10 business days), deadlines for filing objections to the inspection report by the taxpayer (from 5 business days - up to 10 business days) and deadlines for issuing tax notifying decisions (from 10 business days - up to 15 business days). Of course, when reforming the SFS bodies, the need to ensure the quality of work of its employees in the future should not be forgotten as well; and the quality depends on the validity of the planned tasks and their compliance with timing of certain types of inspections. There is no need to save funds on maintenance of the SFS bodies reducing the quality of their work, which ultimately consists in filling the revenue part of the state and local budgets. Attention should be paid to the sound standardization of work of SFS inspectors. It is the right determination of time limit to carry out certain operations to verify the tax statements of business entities that guarantees elimination of risk of misjudgments and subsequent disputes between entrepreneurs and the SFS. At the same time, achievements of the Industrial Revolution (Industry 4.0) should be taken into account, which should lead to serious changes in the activities of fiscal authorities when inspectors will be replaced by "robots" [20].

Thus, efficient functioning of the budgetary system, for which the taxation system organizes filling of the revenue part using tax and non-tax flows, depends on proper organization of the tax work of SFS bodies and taxpayers. Therefore, organization of the effective work of SFS bodies and taxpayers provides for effective monitoring of tax and non-tax flows, digitization of work, 


\section{Alieksieiev, S. Paranchuk, O. Chervinska}

introduction of electronic inspections and of integrated automated system of state supervision (control).

\section{References}

1. Zakon Ukrainy Pro derzhavnu podatkovu sluzhbu v Ukraini vid 24.12.1993 r. No. 3813-KhII [Law of Ukraine on Tax Service in Ukraine] [in Ukrainian]

2. Podatkovyi kodeks Ukrainy vid 02.12.2010 r. No. 2755-VI [Tax code of Ukraine from December 02 2010, No. 2755-VI] [in Ukrainian]

3. Biudzhetnyi kodeks Ukrainy vid 08.07.2010 r. No.2456 -VI [Budget code of Ukraine from July 08 2010 No. 2456 -VI][Elektronnyi resurs]. - Rezhym dostupu: http://zakon3.rada.gov.ua/laws/show/ 2456-17

4. Postanova KM Ukrainy "Pro zatverdzhennia polozhennia pro DFS Ukrainy" vid 31.03.2015r. No. 153.

5. Postanova KM Ukrainy "Pro Derzhavnu fiskalnu sluzhbu v Ukraini" vid 21.05.2014r. No. $216 \mathrm{iz}$ zminamy, vnesenymy Postanovoiu KM Ukrainy vid 01.10.2014r. No. 502, vid 22.07.2015r. No. 548, vid 04.11.2015r. No. 892.

6. DFS Ukrainy. Nakaz "Pro vvedennia $v$ diiu struktury DFS Ukrainy" vid 23.07.2015 r. No. 535.

7. Source: https://www.ukrinform.ua/rubric-economy/ 2797596-riven-tinovoi-ekonomiki-v-ukrainistanovit-majze-polovinu-vid-vvp.html

8. Tin'ova economika v Ukraine. Resultaty doslidgennya 2019 roku. Source: https://www.kiis.com.ua/?lang= $u k r \&$ cat $=$ reports \&id $=897$ \& page $=1$

9. Oryshchyn T. Optimization of the tax burden of the enterprise: the theoretical and methodical aspects. Economika I derzava. No. 4, 2019. S. 58-62. DOI: $10.32702 / 2306-6806.2019 .4 .58$

10. Optymizaciya podatkiv. Source: https://www.tax.agtl. com.ua/monitoring-of-tax-risks/optymizatsiyapodatkiv

11. Source: http://www.buhuslugi.com.ua/ua/ informatsiya/informatsiya-dlya-yuridichnikhosib/optimizatsiya-podatkovogonavantazhennya-minimizatsiya-podatkiv.html

12. Source: https://opendatabot.ua/blog/31-bankruptcy

13. Source: http://www.ukrstat.gov.ua/express/ expr2020/01/10.pdf

14. Kravchenko $O$. $O$. The dynamics of enterprise bankruptcy and unemployment level. Young Scientist. No. 3 (43) March, 2017. S. 691-697. Source: http://molodyvcheny.in.ua/files/journal/ 2017/3/160.pdf.

15. Desiatniuk O., Dmytriv V. Stabilnist opodatkuvannia ta yii vplyv na ekonomichnyi rozvytok derzhavy //
O. Desiatniuk, V. Dmytriv / Svit finansiv. 2016. No. 2(47). S. 18-27. ISSN 1818-5754

16. Iefymenko T. I. Fiskalna ta monetarna bezpeka natsionalnoi ekonomiky / T. I. Iefymenko; DNNU “Akad. fin. upravlinnia”. K., 2016. 447 s.

17. Zamaslo O. T. Podatkova systema Ukrainy: teoriia, metodolohiia, praktyka : monohrafiia. Lviv: LNU imeni Ivana Franka, 2017. 420 s.

18. Yvanov $Y$ и. B. Tendentsyy myrovoi nalohovoi polytyky $v$ kontekste antykryzysnoho rehulyrovanyia / Nalohovye reformy. Teoryia y praktyka: monohr; [pod. red. Y. A. Maiburova, Yu. B. Yvanova ]. M.: Iunyty-Dana, 2010. S. 381-395.

19. Krysovatyi A. I. Sutnist ta kontseptualni osnovy formuvannia podatkovoi polityky $v$ umovakh yevrointehratsiinykh protsesiv / A. I. Krysovatyi, V. M. Melnyk, T. V. Koshchuk // Ekonomika Ukrainy, 2016. No. 1(650). S. 35-36.

20. Krupka M. I. Systema administruvannia podatkiv $v$ Ukraini: stan, problemy ta perspektyvy / M. I. Krupka, V. M. Kmit, R. Iu. Paslavska // Naukovyi visnyk NLTU Ukrainy. 2016. Vyp. 26.2. S. 217-224.

21. Kuzmin O. Ye. Osoblyvosti opodatkuvannia subiektiv zovnishnoekonomichnoi diialnosti / O. Ye. Kuzmin, A. V. Todoshchuk, O. H. Melnyk // Visnyk Natsionalnoho universytetu "Lvivska politekhnika". Menedzhment ta pidpryiemnytstvo $v$ Ukraini: etapy stanovlennia i problemy rozvytku. 2013. No. 769. S. 138-143. Rezhym dostupu: http://nbuv.gov.ua/UJRN/VNULPM_2013_769_22.

22. Sokolovska A. M. Neobkhidnist ta shliakhy podalshoho reformuvannia podatkovoi systemy Ukrainy / Modernizatsiia finansovoi systemy Ukrainy $v$ protsesi yevrointehratsii. $U$ 2t.; [za red. O. V. Shlapaka, T. I. Iefymenko]. K.:DNNU “Akad. fin. Upravlinnia”, 2014. T. 1. S. 117-143.

23. Iefymenko T. I. Osnovni napriamy transformatsii podatkovoi systemy v Ukraini / T. I. Iefymenko // Finansy Ukrainy. 2007. No. 9. S. 9-13. Rezhym dostupu: http://nbuv.gov.ua/UJRN/Fu_2007_9_3.

24. Melnyk V. N. K voprosu o neobkhodymosty korrektsyy nalohovoi polytyky $v$ Ukrayne / V. N. Melnyk, T. V. Koshchuk // Voprosy sovremennoi ekonomyky. 2013. No. 3. S. 100-117.

25. Alieksieiev I. V. Upravlinnia podatkovym navantazhenniam pidpryiemstv / I. V. Alieksieiev, S. V. Paranchuk, O. S. Chervinska, N. H. Syniutka // Rehionalna ekonomika. Naukovo-praktychnyi zhurnal Instytutu rehionalnykh doslidzhen NAN Ukrainy. Lviv, 2016. 4(82). S. 145-153.

26. Khomutenko V., Lutsenko I. Monitoryng suchasnogo stanu podatkovykh nadkhodgen' do 


\section{Monitoring of tax and non-tax flows}

Zvedenoho biudzhetu Ukrainy. Visnyk TNEU № 5-1, 2011, P. 292-302.

27. I. Lutsenco, The monitoring current state of tax revenues from foreign trade activity in the stage budget of Ukrain. Economika ta dergava, № 6, 2015. S. 66.

28. Babichenko V., Ghlukhova V., Kolotij J., Analysis of the Formation of the Revenue Base of the State Budget of Ukraine and Assessment of Budget Risks. Electronne naukove fakhove vydannya $z$ economichnykh nauk Modern Economics, №14 (2019), 19-25 https://modecon.mnau.edu.ua | ISSN 2521-6392. DOI: https://doi.org/10.31521/ modecon.V14(2019)-03.

29. Zakharkina L. S. Role and place of tax revenues in the structure of consolidated budget of Ukraine. Naukovy visnyk Mizhnarodnogo humanitarnogo universitetu, 2016. C. 125-129.

30. Zolotaryova O. V., Kostenko I. S. Monitoring of tax revenues to the state budget and the system of tax administration of Ukraine. Economika $i$ suspilstvo. Vypusk № 17. 2018. S. 533-542. DOI: https://doi.org/10.32782/2524-0072/2018-17-79.

31. Sait Derzhavnoi fiskalnoi sluzhby Ukrainy. Zvit pro rezultaty otsinky systemy podatkovoho administruvannia Ukrainy za dopomohoiu Diahnostychnoho instrumentu otsinky podatkovoho administruvannia (TADAT) [Website of the State fiscal service of Ukraine. Report on the results of the assessment of the tax administration system in Ukraine through the Tax Administration Assessment Diagnostic Tool (TADAT)]. Available at: http://sfs.gov.ua/ diyalnist-/plani-ta-zviti-roboti1339853.html (accessed 11 July 2018).
32. Nikitishin A. O. The Adaptive and Coherent Institutional Architectonics of Tax Regulation. Problemy economiky, № 1 (35), 2018, C. 300-307.

33. Nikitishin A. O. The main directions of the improvement of a mechanism of the tax regulation. Electronny jurnal Efectyvna economika, № 2, 2016.

34. Vykolayec A. Podatkovy control: teoretychni zasady $i$ practyka zastosuvannya $v$ umovakh reformuvannya economiky Ukrainy. Dergavne upravlinnya: udoskonalennya ta rozvytok, № 12, 2016.

35. Nikitishyn A., Saenko Ya. Analysis of formation of revenues of local budgets. Journal naukovy oglyad, № 2(45), 2018.

36. Glukhova V. I., Skrypnyk L. I. Financing of the Public Health Services at the Level of Local Budgets. Oblik i finansy, № 1 (79) 2018. C. 80-86.

37. Goloborodko T. V., Shmagaylo S. S. Doslidgennya podatkovykh nadkhodgen: dergava, galuzi, region. Electronne naukove fakhove vydannya Efectyvna economika. № 2, 2016. www.economy.nauka.com.ua

38. Pleskach $V$. statystychnyi analiz podatkovykh nadkhodzhen do Zvedenoho biudzhetu Ukrainy / V. Pleskach // Visnyk Kyivskoho natsionalnoho universytetu im. T. Shevchenka. Ekonomika, 2012. № 139. S. 5-10.

39. Tkachyk F. P. Udoskonalennia podatkovoho kontroliu v Ukraini u konteksti protydii ukhylenniu vid opodatkuvannia / F. P. Tkachyk // Ekonomichnyi chasopys KhKhI, 2017. № 4. S. 133-137.

40. Vishnevsky V. P., Chekina V. D. Robot vs. tax inspector or how the fourth industrial revolution will change the tax system: a review of problems and solutions. Journal of Tax Reform, 2018, vol. 4, no. 1, pp. 6-26. DOI: 10.15826/jtr.2018.4.1.042 